\title{
Factor analysis identifying key values held by South Australian and Victorian irrigators in a time of severe drought
}

\author{
S. Wheeler ${ }^{1}$, C. Lane-Miller ${ }^{1}$, A. Zuo ${ }^{1}$ \& H. Bjornlund ${ }^{1,2}$ \\ ${ }^{1}$ CRMA, School of Commerce University of South Australia, \\ Adelaide, Australia \\ ${ }^{2}$ Economics Department, University of Lethbridge, Alberta, Canada
}

\begin{abstract}
This study uses factor analysis to analyse the results of a telephone survey undertaken in the Riverland, South Australia $(\mathrm{n}=324)$ and the Goulburn Murray Irrigation District of Victoria $(\mathrm{n}=300)$ in 2008-09, a time of severe drought in the southern Murray Darling Basin. It reports the results of 56 different attitudinal questions, covering the dimensions of family, profit, land, water, community, lifestyle, and technology/innovation. Factor analysis was used to identify the underlying value constructs from these questions, with five main factors identified. They were named Succession (variables all related to the dimension of family); Commerce (related to the profitability of the farm business); Tradition (related to the lifestyle of farming); Environment (related to the environment); and Technology (related to adopting new technologies). Our findings were very similar to other typology research conducted with irrigators in different areas of the Murray Darling Basin.
\end{abstract}

Keywords: irrigator attitudes, values, water, Australia, factor analysis.

\section{Introduction}

Private land owners are critical to the sustainable management of natural resources. Consequently, efforts are growing to better understand the motivations, needs, and behaviours of these private land managers, as sustainable land management often requires changes in their land management practices. However, understanding land managers' decisions is neither straight-forward nor simple. While a number of studies have attempted to identify land managers' 
motivations and actions, much remains to be understood. In particular, generalized descriptions of different landowner types can help policy makers to develop more applicable and acceptable policies and programs.

In Australia, irrigators are particularly important partners in efforts to achieve more sustainable water use. The country has experienced numerous droughts, which has spurred calls for more efficient and sustainable water use, particularly as the negative environmental impacts of over-extraction on wetlands and other river ecosystems have become apparent. Accordingly, the Commonwealth and state governments have developed a number of programs, policies, and incentives to encourage more sustainable water extraction levels. The most recent is a large-scale effort to buy back water rights from voluntary sellers. The success of these programs depends largely on how irrigators respond to these programs. Because not all irrigators will respond in similar ways, it is important to understand why irrigator responses vary and what can be done to improve programs in order to increase irrigator acceptance. Several studies [1-3] have attempted to identify and categorize different types of farmers, but more information is needed to help understand farmers' behaviours and decisions during times of drought.

This study reports results of a telephone survey undertaken in the Riverland, South Australia $(\mathrm{n}=324)$ and the Goulburn Murray Irrigation District of Victoria $(\mathrm{n}=300)$ in 2008-09, a time of severe drought in the southern Murray Darling Basin. We include the results of 56 different attitudinal questions, covering the dimensions of family, profit, land, water, community, lifestyle, and technology/innovation.

\section{Literature review}

As it becomes clearer that landowners, particularly farmers, are not homogenous in their values, attitudes, and behaviours, an increasing number of studies have attempted to identify these differences and demonstrate the connection between values and attitudes and land management practices [1, 2, 4-6]. Drawing from sociological, psychological, and marketing literature, these and other studies have attempted to separate farmers into a number of different categories and classifications that are useful for creating more effective natural resource management policies. There is considerable debate about whether to classify farmers and how to go about doing so [7,8], but most studies agree that it is beneficial to view farmers as heterogenous in the values and attitudes which influence their decision-making and behaviours [9].

Despite discussion about how best to categorize farmers for research and policy purposes, numerous studies have attempted to identify important characteristics, values, and attitudes which influence farmers' behaviours. Farmer typology research has become useful as a way of segmenting farmers into groups to assist in developing targeted farm extension programs [10]. In particular, substantial work has been done to classify Australian farmers, which helps to provide a framework for this study. 
Maybery et al. [1] found that farmers in the New South Wales catchment of the Murray River could be divided into three partially overlapping categories: economic, conservation, and lifestyle (yeoman). In particular, they noted that responses were substantially different between economic- and conservationminded farmers, who were thus unlikely to both be motivated by the same policy incentives, such as tax rebates.

Schwarz et al. [10] found that catering to different farming styles led to higher conversion levels to more efficient piped water supply in Australia's Wimmera Mallee region. They argue that an understanding of farmer typologies can improve efforts to encourage adoption of new technologies or land management practices. Waters et al. [11] surveyed 450 dairy farmers and found evidence of six groups: 'family;' 'winding down;' 'love family;' 'established and stable;' 'open to change;' and 'growing for the kids.'

Kuehne et al. [2] used principal component analysis to divide farmers from Australia's Lower Murray Reclaimed Irrigation Area into three groups (Custodian, Investor, Lifestyler) based on responses to questions regarding family, land, water, profit and community. Custodians were focused on continuing the family business; Investors on financial gain, and Lifestylers on continuing farming traditions and preserving the land. Similarly, Kuehne and Bjornlund [12] hypothesised that irrigators in Australia's Namoi Valley were responding to upcoming reductions to their water allocations depending on whether they were more profit-oriented and wanted to receive the most from their water (Investors), or motivated more by non-economic factors (Custodians). Through personal interviews and a mail-out survey they found examples of farmers representing these two typologies. These typologies were meant to help policy makers understand various responses to new drought measures introduced in the irrigation district, with an eye toward increasing the sophistication of future drought-related policies and programs.

Following [12], Kuehne [3] and Kuehne and Bjornlund [13] explored the values that farmers in the Namoi valley held towards land, water, profit, family, lifestyle, and community based on their responses to a number of value statements reflecting each of these six dimensions. Factor analysis was applied and three value constructs emerged: Succession, Caretaking and Commerce. The Succession construct included statements related to the value of family. The Caretaking construct included statements related to good land management practices, responsible water use and an acceptance of the fact that children might choose careers other than farming. The Commerce construct included statements that were more related to the achievement of profit, without an emphasis on family succession. Irrigators did not see these value constructs as mutually exclusive [13], as the same irrigators could score highly on more than one value construct. Figure 1 shows overlapping values held by respondents scoring above the $40^{\text {th }}$ percentile on each value construct.

To explore this further, cluster analysis was applied to the value statements in order to group farmers which held similar values [13]. Three clusters emerged: Traditionals (practicing conservative farming), Expanders (seeking to grow their farm business), and Investors (profit-oriented). Each cluster interacted with 




Figure 1: Overlapping value constructs [13].

different value constructs and the dimensions of profit, family and land. For example, both investors and expanders align with the commerce value construct. Investors relate strongly with only the profit dimension while expanders align with both the profit and family dimensions which in turn are influenced by the 'succession' value construct. In essence, for farmers to successfully pursue their succession values they need to expand; to accomplish that they need to also pursue the profit dimension, which is reflected in the commerce value construct. This study was the first to explore the interconnectedness of farmers' values.

As in [13], this paper also looks at the dimensions of family, profit, land, water, community, lifestyle, and technology/innovation, but is derived from a much larger study conducted four years later in different irrigation areas in Australia and in the grips of the worst drought in recorded history. Farmers living in these irrigation districts were presumably experiencing different pressures than those in the Namoi Valley of NSW, and thus this study helps to provide insight into how these particular dimensions influence irrigator behaviour and decision-making during a prolonged drought.

\section{Methodology}

\subsection{Data collection}

Our study areas in 2008-09 were the Riverland in South Australia and the Goulburn Murray Irrigation District (GMID) in northern Victoria. The majority of the farmers in the Riverland have permanent plantings, while farmers in the GMID are primarily dairy farmers. A telephone survey collected information from 324 irrigators in the Riverland and 300 in the GMID on a variety of irrigator farmer and farm characteristics, as well as 56 value and attitude statements developed from previous attitudinal research [13]. The attitudinal statements asked respondents to rate their agreement with each statement using a five-point Likert scale. 


\subsection{Factor analysis}

We used factor analysis to identify key irrigator attitudinal constructs from the large set of attitudinal statements asked in the survey, and did this for each irrigation region. Factor analysis is a statistical method used to identify a small set of unobserved variables (also called factors) which can account for the covariance among a larger set of observed variables. For this study different factors will be identified based on the responses to the attitudinal statements. Each of the factors can then be given an identity based on the nature of the attitudinal statements with high factor loadings contributing to that factor. Principal Components Factor Analysis was used to fit the data to reduce the number of variables into a manageable number of factors [14]. Promax rotation was used and factor loadings below 0.30 were considered as insignificant (both statistically [15] and practically [16] and thus dropped. Bartlett's test and the Kaiser-Meyer-Olkin Measure of Sampling Adequacy was used to test the data. Thomson's regression method [18] could also be used to predict the five factor scores for each irrigator and further analyses such as regressions could be undertaken using the factor scores.

As the Thomson's regression method produces a factor score with an average of zero, we can divide irrigators into two groups based on their factor score: a group that is more oriented toward the factor construct (factor score greater than zero) and a group that is less oriented toward the factor construct (factor score less than zero). When the two groups are identified, their characteristics could also be summarised and compared, including socioeconomic, farm-related, and attitudinal characteristics. We also undertook analysis to highlight the extent of overlapping values held by irrigators scoring above the $40^{\mathrm{th}}$ percentile on each value construct.

\section{Results}

For the Riverland region, 19 value statements from the initial 56 were included in the final factor analysis after 37 unsuitable statements were removed; for the GMID, 15 value statements were included in the final factor analysis.

The total variance accounted for by the five factors for Riverland was $54.2 \%$ and this was regarded as satisfactory [16], while the total variance for GMID was $59.4 \%$. For the Riverland, five factors with eigenvalues of 3.29, 2.37, 1.99, 1.39 and 1.25 were identified, which accounted for $17,13,11,7$ and 7 percent of the variance respectively. For the GMID, the five factors identified had eigenvalues of $3.03,2.06,1.51,1.24$ and 1.07, which accounted for $20,14,10,8$ and 7 percent of the variance respectively.

The diagnosis indicated the appropriateness of the retained variables for factor analysis. Specifically the determinant of the correlation matrix was 0.022 and 0.055 for Riverland and GMID respectively (this determinant will equal 1.0 only if all correlations equal 0); Bartlett's test (null hypothesis: variables are not intercorrelated) was rejected for both Riverland and GMID, and the KaiserMeyer-Olkin Measure of Sampling Adequacy was 0.734 and 0.714 for them respectively (unacceptable if below 0.5 [18]). 
Table 1: Questions identified in factor analysis of the 2008-09 data.

\begin{tabular}{|c|c|c|c|c|c|c|c|c|c|c|}
\hline & \multicolumn{5}{|c|}{ Riverland } & \multicolumn{5}{|c|}{ GMID } \\
\hline Variable & 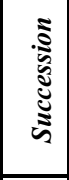 & 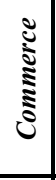 & 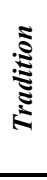 & 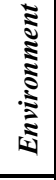 & 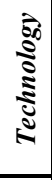 & 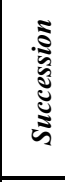 & 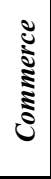 & 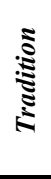 & 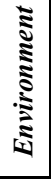 & $\frac{\overrightarrow{3}}{\frac{3}{3}}$ \\
\hline $\begin{array}{l}\text { q1. Family should be an integral part of the } \\
\text { farming enterprise }\end{array}$ & 0.8 & & & & & 0.6 & & & & \\
\hline $\begin{array}{l}\text { q2. I would like some or all of my family to } \\
\text { continue farming }\end{array}$ & 0.7 & & & & & 0.8 & & & & \\
\hline $\begin{array}{l}\text { q3. Farmers should encourage family } \\
\text { members to be involved in family farm }\end{array}$ & 0.8 & & & & & 0.8 & & & & \\
\hline $\begin{array}{l}\text { q4. I would like to buy or develop enough } \\
\text { land for my family to remain or to become } \\
\text { farmers }\end{array}$ & 0.6 & & & & & 0.7 & & & & \\
\hline $\begin{array}{l}\text { q5. Financial gain is the only reason for my } \\
\text { involvement in farming }\end{array}$ & & 0.7 & & & & & & & & \\
\hline $\begin{array}{l}\text { q6. Dollars and cents is what farming is all } \\
\text { about. }\end{array}$ & & 0.7 & & & & & 0.8 & & & \\
\hline $\begin{array}{l}\text { q7. A maximum annual return from my } \\
\text { property is my most important aim }\end{array}$ & & 0.7 & & & & & & & & \\
\hline $\begin{array}{l}\text { q8. I view my farm as first and foremost a } \\
\text { business enterprise }\end{array}$ & & 0.6 & & & & & & & & \\
\hline $\begin{array}{l}\text { q9. My land is just something I use to } \\
\text { generate an income }\end{array}$ & & 0.7 & & & & & 0.7 & & & \\
\hline $\begin{array}{l}\text { q10. I could never imagine living anywhere } \\
\text { other than this area }\end{array}$ & & & 0.8 & & & & & 0.8 & & \\
\hline $\begin{array}{l}\text { q11. I want to continue farming for as long } \\
\text { as I am able }\end{array}$ & & & 0.6 & & & & & 0.5 & & \\
\hline $\begin{array}{l}\text { q12. Farming is the only occupation I can } \\
\text { imagine doing }\end{array}$ & & & 0.7 & & & & & 0.6 & & \\
\hline $\begin{array}{l}\text { q13.My life would be worse if I moved } \\
\text { from this farm }\end{array}$ & & & 0.7 & & & & & 0.8 & & \\
\hline $\begin{array}{l}\text { q14.I try to preserve the beauty of the } \\
\text { countryside }\end{array}$ & & & & 0.7 & & & & & 0.8 & \\
\hline $\begin{array}{l}\text { q15. Managing environ. problems on my } \\
\text { farm is a very high priority }\end{array}$ & & & & 0.7 & & & & & 0.7 & \\
\hline $\begin{array}{l}\text { q16.I am willing to do something about the } \\
\text { environmental effects of my farming } \\
\text { practices }\end{array}$ & & & & 0.6 & & & & & 0.6 & \\
\hline $\begin{array}{l}\text { q17.The wider community can reasonably } \\
\text { expect landholders to adopt recommended } \\
\text { practices that lead to improved } \\
\text { environmental outcomes }\end{array}$ & & & & 0.7 & & & & & & \\
\hline $\begin{array}{l}\text { q18. Knowing about new technology that } \\
\text { becomes available is important to me }\end{array}$ & & & & & 0.9 & & & & & 0.9 \\
\hline $\begin{array}{l}\text { q19. I am open to new ideas and } \\
\text { alternatives about farming }\end{array}$ & & & & & 0.8 & & & & & 0.9 \\
\hline Proportion of Variance Explained & 13 & 11 & 17 & 7.3 & 6.6 & 20 & 7.1 & 14 & 8.3 & 10 \\
\hline Determinant of the correlation matrix & 0 & & & & & 0.1 & & & & \\
\hline Bartlett test of sphericity (Chi2; pvalue) & 1157. & $; 0.00$ & & & & 822.1 & 0.00 & & & \\
\hline $\begin{array}{l}\text { Kaiser-Meyer-Olkin Measure of Sampling } \\
\text { Adequacy }\end{array}$ & 0.7 & & & & & 0.7 & & & & \\
\hline
\end{tabular}


Table 1 displays the relevant questions that were identified. For the first factor, they were all related to the dimension of family; hence we named this value construct Succession. The variables included in the second factor are all related to the profitability of the farm business; hence, it was named Commerce. The third factor included variables related to how embedded the farmer is in the farming tradition and lifestyle and was therefore called Tradition. The fourth factor (labelled Environment) included variables reflecting the farmers' willingness to manage their land with the environment in mind and the reasonableness of the wider community to expect farmers to consider the environment in their decision making. The fifth factor included variables reflecting the farmers' preparedness to embrace new technology and was therefore labelled Technology. The higher the factor score, the more the farmers associate themselves with the values embedded in that construct.

Appendix A provides more detail on how irrigators in the Riverland and GMID responded to each question.

\section{Discussion}

Our results have identified five factor constructs across two irrigation regions: Tradition, Succession, Commerce, Environment, and Technology. The higher the factor score, the more the farmers associate themselves with the values embedded in that construct. The characteristics of farmers within each construct are discussed below.

\subsection{Tradition}

Farmers who associated strongly with the tradition construct are those who believe strongly in the farming lifestyle, want to stay on the farm as long as possible, and could not see themselves doing anything else. An analysis of their characteristics shows that farmers (across both the GMID and the Riverland) who strongly associate with this construct tend to be slightly older and to have worked for more years on the farm, have larger farms (with less of them in permanent crops), hold slightly higher absolute debt and less water entitlements, more of them have in place a successor and a whole-farm plan for their farm, and fewer tend to use government or private organisations for information. Farmers who identify strongly with the tradition construct also identify with all other constructs (succession, commerce, environment and innovation), but the value construct they feel most positively and strongly about is succession.

\subsection{Succession}

Farmers who associated strongly with the succession construct are those who believe strongly in the role of the family on the farm: they want their children to take over the farm and they would like to keep developing and building their farm for their family. Farmers (across both the GMID and the Riverland) who strongly associate with the construct are more likely to be male and to have worked for more years on the farm, to have larger farms, to have a successor and a whole farm plan in place, and to have slightly higher absolute debt and larger 
water entitlements. Farmers who identify strongly with the succession construct also identify with all other constructs (tradition, environment and innovation) with the exception of the commerce construct. As to be expected from above, the value construct they feel most positively and strongly about was tradition.

\subsection{Commerce}

Farmers who associated strongly with the commerce construct are those who believe strongly in making money from farming, and keeping emotion out of the farming lifestyle, and feel that obtaining the maximum profit from the farm. is the most important objective. Farmers (across both the GMID and the Riverland) who strongly associate with commerce values are more likely to be slightly older, male, to have worked for more years on the farm, have larger farms and a whole farm plan in place, while fewer of them have a successor in place. GMID farmers have less debt and water entitlements while Riverland farmers have higher absolute debt levels and larger water entitlements. This is likely to reflect the different nature of farming in the two regions. The production in the Riverland is almost entirely permanent plantings in viticulture and horticulture which is very capital intensive. Hence these businesses are associated with higher debt levels. On the other hand, the GMID is dominated by broadacre annual productions which are less capital intensive. All farmers identifying with the commerce construct tend not to cite government organisations as information sources. Riverland farmers who identify strongly with the commerce construct also identify with tradition and innovation, but they do not identify positively with succession and environment. On the other hand, GMID farmers who identified strongly with commerce values did not identify positively with any other value construct.

\subsection{Environment}

Farmers who associated strongly with the environment construct are those who believe strongly in trying to address environmental problems on their farm, in preserving the beauty of the countryside, and feel that farmers should be expected by the wider community to take more responsibility over adopting improved environmental practices on the farm. Farmers (across both the GMID and the Riverland) who strongly associate with this construct are more likely to be male, have larger farms, have a successor and a whole farm plan in place, and have slightly higher absolute debt and larger water entitlements. They have also adopted more efficient irrigation infrastructure in the past five years, and a higher percentage belong to organisations like Landcare and Waterwatch. Farmers who identify strongly with the environment construct also identify with all other constructs (succession, environment and innovation) with the exception of the commerce construct. The value construct they feel most positively and strongly about is tradition.

\subsection{Technology}

Farmers who associated strongly with the technology construct are those who like to know about new innovations, learn about new ideas and gather 
knowledge. Farmers (across both the GMID and the Riverland) who strongly associate with the construct are more likely to be younger, male, to have larger farms, to have a successor and a whole farm plan in place, and to have slightly higher absolute debt and larger water entitlements. They have also adopted more efficient irrigation infrastructure in the past five years, and a higher percentage belong to organisations like Landcare and Waterwatch. Farmers who identify strongly with the innovation construct also identify with the environment, though Riverland farmers also identify with tradition and family while GMID farmers are less likely to identify with other value constructs.

\subsection{General discussion}

The need to assess the rigour of these typologies and their application is recognised. Like Maybery et al. [1] study of irrigators in the NSW catchment of the Murray, Kuehne et al.'s [2] study of irrigators in the Lower Murray, and Kuehne's [3] study of NSW Namoi irrigators, we found evidence of all their value constructs (namely our commerce, succession, environment and tradition), but we also found additional evidence in our two regions for innovation-minded irrigators. This could suggest that after being exposed to an extended period of drought, irrigators are showing an increased willingness to embrace new technology as a means of managing increased scarcity, which could have important ramifications for policies designed to encourage more efficient water use.

Just over $40 \%$ of irrigators fall into only one factor construct, but the remaining had overlapping values. A small proportion of irrigators (mean of 5\%) hold overlapping values of all typologies (that is, they identify with all five value constructs). This was most relevant between tradition and succession constructs: a quarter of all respondents who felt strongly about tradition also felt strongly about succession issues. The next largest relationship was between environmental and technology values.

\section{Conclusion}

Ongoing assessment of the value constructs will provide insight into whether typologies such as those applied in this paper remain valid over time. We found evidence of five major value constructs of irrigators: namely tradition, succession, commerce, environment and innovation. Further research using these value-constructs as variables in regression analysis on farmer behaviour will help identify how important these value constructs actually are. We are currently conducting follow-up research to track farmer practice and behaviour changes across the southern Murray Darling Basin. This will also provide an opportunity to evaluate whether the typologies identified here are applicable across a larger sample of irrigators and regions. This research will contribute to the debate on the value of typology research in extension activities, and whether issue-specific typologies can have a wider application in behavioural analysis. 


\section{Appendix A: detailed responses (\%) to the attitudinal questions identified through factor analysis}

\begin{tabular}{|c|c|c|c|c|c|c|c|c|c|c|}
\hline & \multicolumn{5}{|c|}{ Riverland } & \multicolumn{5}{|c|}{ GMID } \\
\hline Variable & 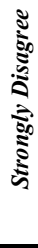 & 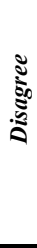 & $\frac{\sum^{2}}{\Sigma}$ & $\stackrel{\square}{\frac{\pi}{8}}$ & 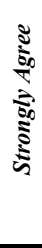 & 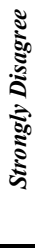 & 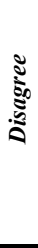 & $\frac{\sum^{2}}{\Sigma}$ & $\stackrel{2}{5}$ & 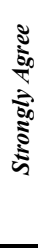 \\
\hline $\begin{array}{l}\text { q1. Family should be an integral part of the } \\
\text { farming enterprise }\end{array}$ & 1 & 24 & 14 & 56 & 5 & 0 & 17 & 10 & 61 & 12 \\
\hline $\begin{array}{l}\text { q2. I would like some or all of my family } \\
\text { to continue farming }\end{array}$ & 6 & 49 & 13 & 30 & 2 & 2 & 33 & 16 & 43 & 6 \\
\hline $\begin{array}{l}\text { q3. Farmers should encourage family } \\
\text { members to be involved in family farm }\end{array}$ & 4 & 40 & 12 & 42 & 2 & 1 & 24 & 15 & 53 & 6 \\
\hline $\begin{array}{l}\text { q4. I would like to buy or develop enough } \\
\text { land for my family to remain or to become } \\
\text { farmers }\end{array}$ & 6 & 55 & 8 & 26 & 4 & 1 & 43 & 14 & 36 & 6 \\
\hline $\begin{array}{l}\text { q5. Financial gain is the only reason for } \\
\text { my involvement in farming }\end{array}$ & 4 & 57 & 10 & 29 & 2 & 6 & 71 & 9 & 13 & 0 \\
\hline $\begin{array}{l}\text { q6. Dollars and cents is what farming is all } \\
\text { about. }\end{array}$ & 2 & 43 & 12 & 40 & 4 & 2 & 51 & 10 & 36 & 1 \\
\hline $\begin{array}{l}\text { q7. A maximum annual return from my } \\
\text { property is my most important aim }\end{array}$ & 1 & 23 & 7 & 64 & 5 & 0 & 29 & 9 & 59 & 3 \\
\hline $\begin{array}{l}\text { q8. I view my farm as first and foremost a } \\
\text { business enterprise }\end{array}$ & 1 & 20 & 7 & 64 & 8 & 0 & 21 & 7 & 64 & 8 \\
\hline $\begin{array}{l}\text { q9. My land is just something I use to } \\
\text { generate an income }\end{array}$ & 2 & 42 & 9 & 45 & 2 & 3 & 54 & 10 & 32 & 1 \\
\hline $\begin{array}{l}\text { q10. I could never imagine living } \\
\text { anywhere other than this area }\end{array}$ & 4 & 44 & 6 & 39 & 6 & 2 & 49 & 7 & 38 & 4 \\
\hline $\begin{array}{l}\text { q11. I want to continue farming for as long } \\
\text { as I am able }\end{array}$ & 2 & 17 & 5 & 68 & 9 & 0 & 12 & 5 & 68 & 16 \\
\hline $\begin{array}{l}\text { q12. Farming is the only occupation I can } \\
\text { imagine doing }\end{array}$ & 5 & 56 & 3 & 32 & 4 & 3 & 41 & 5 & 42 & 8 \\
\hline $\begin{array}{l}\text { q13.My life would be worse if I moved } \\
\text { from this farm }\end{array}$ & 3 & 43 & 17 & 31 & 6 & 2 & 38 & 19 & 32 & 9 \\
\hline $\begin{array}{l}\text { q14.I try to preserve the beauty of the } \\
\text { countryside }\end{array}$ & 0 & 2 & 2 & 85 & 11 & 0 & 1 & 3 & 85 & 11 \\
\hline $\begin{array}{l}\text { q15. Managing environ. problems on my } \\
\text { farm is a very high priority }\end{array}$ & 0 & 9 & 9 & 71 & 10 & 0 & 7 & 10 & 73 & 10 \\
\hline $\begin{array}{l}\text { q16.I am willing to do something about the } \\
\text { environmental effects of my farming } \\
\text { practices }\end{array}$ & 0 & 4 & 9 & 77 & 9 & 0 & 4 & 6 & 81 & 9 \\
\hline $\begin{array}{l}\text { q17. The wider community can reasonably } \\
\text { expect landholders to adopt recommended } \\
\text { practices that lead to improved } \\
\text { environmental outcomes }\end{array}$ & 0 & 6 & 11 & 81 & 3 & 1 & 13 & 16 & 68 & 2 \\
\hline $\begin{array}{l}\text { q18. Knowing about new technology that } \\
\text { becomes available is important to me }\end{array}$ & 0 & 4 & 2 & 77 & 16 & 1 & 7 & 4 & 75 & 13 \\
\hline $\begin{array}{l}\text { q19. I am open to new ideas and } \\
\text { alternatives about farming }\end{array}$ & 0 & 5 & 3 & 80 & 13 & 0 & 3 & 3 & 82 & 12 \\
\hline
\end{tabular}




\section{References}

[1] Maybery, D., Crase, L. and Gullifer, C., Categorising farming values as economic, conservation and lifestyle, Journal of Economic Psychology, 26, $59-72,2005$.

[2] Kuehne, G., Bjornlund, H. and Cheers, B., There is more than one type of farmer, International Journal of Interdisciplinary Social Sciences, 2(2), 179-186, 2007.

[3] Kuehne, G., The influence of values and attitudes towards family, land, water, community, lifestyle and profit on farmers' behaviour, Centre for Regulation and Market Analysis, Adelaide, Australia, University of South Australia, 269, 2009.

[4] Vogel, S., Farmers' environmental attitudes and behaviour: A case study for Austria, Environment and Behaviour, 28(5), pp. 591-613, 1996.

[5] Busck, A.G., Farmers' Landscape Decisions: Relationships between Farmers' Values and Landscape Practices, Sociologia Ruralis, 42(3), 233249, 2002.

[6] Kuehne, G. and Bjornlund, H., The influence of irrigators' attitudes and objectives on their decision making, Hydrological Research Letters, 2, 27-31, 2008.

[7] Willock, J., Deary, I., Edwards-Jones, G., Gibson, G., McGregor, M., Sutherland, A., Dent, J., Morgan, O. and Grieve, R., The role of attitudes and objectives in farmer decision making: Business and environmentally oriented behaviour in Scotland, Journal of Agricultural Economics, 50(2), pp. 286-303, 1999.

[8] Fish, R., Seymour, S. and Watkins, C., Conserving English landscapes: land managers and environmental policy, Environment and Planning, 35, $19-41,2003$.

[9] Thomson, D., Understanding diversity in farming behaviour using 'farming styles', Wool Technology and Sheep Breeding, 50, pp. 280-286, 2002.

[10] Schwarz, I., McRae-Williams, P. and Park, D., Identifying and utilising a farmer typology for targeted practice change programs: A case study of changing water supply in the Wimmera Mallee, Extension Farming Systems Journal, 5(1), pp. 33-42, 2009.

[11] Waters, W., Thomson, D. and Nettle, R., Derived attitudinal farmer segments: A method for understanding and working with the diversity of Australian dairy farmers, Extension Farming Systems Journal, 5 (2), 47-57, 2009.

[12] Kuehne, G. and Bjornlund, H., 'Custodians' or 'Investors': classifying irrigators in Australia's Namoi Valley. Sustainable Irrigation Management, Technologies and Policies, ed. Lorenzini, G. and Brebbia, C.A., Southampton: WIT Press, 2006.

[13] Kuehne, G. and H. Bjornlund, The drought, the irrigators, and their photographs; Images from the inside. In Brebbia, Marinov and Bjornlund Eds. Sustainable Irrigation III, WITPress Transaction on Ecology and the Environment v 137, Southampton, 241-250, 2010. 
[14] Morrison, M., Durante, J., Greig, J. and Ward, J., Encouraging participation in market based instruments and incentive programs: Final report prepared for Land \& Water Australia, Land \& Water Australia, Canberra, 2008.

[15] Wilson, A., Multivariate analysis: data reduction and treatment evaluation, Brit J of Psychiat, 128, pp.404-407, 1976.

[16] Stevens, J., Applied Multivariate Statistics for the Social Sciences, 4th Ed, Lawrence Erlbaum Associates, Mahwah, NJ, 2002.

[17] Hair, J.F.J., Anderson, R.E., Tatham, R.L. and Black, W.C., Multivariate Data Analysis, 5th Ed, Upper Saddle River, NJ: Prentice Hall, 1998.

[18] Thomson, G.H., The Factorial Analysis of Human Ability, London: University of London Press, 1951.

[19] Kaiser, H., An index of factor simplicity. Psychometri, 39, 31-36, 1974. 